\title{
Caring for students in postsecondary open educational resource (OER) and open education initiatives: inviting student participation and voice
}

\author{
Merinda McLure and Caroline Sinkinson \\ Success and Engagement Chapter, University Libraries, \\ University of Colorado Boulder, Boulder, Colorado, USA
}

\begin{abstract}
Purpose - This paper aims to examine librarians' professional motivations and theoretical perspectives to attend to care and student voice, as they pursue open educational resource (OER) initiatives in higher education.

Design/methodology/approach - The authors examine OER initiatives that serve as models for their work at the University of Colorado Boulder (CU Boulder), describe how they have attended to care and student voice in their work to date and reflect on how they hope to continue to do so in their future OER initiatives.

Findings - The authors find connections between theoretical perspectives for care in education and the values and ethics of both the open education movement and librarianship. They propose that these connections provide a foundation for librarians to align their professional motivations and practices in support of learning. The authors provide examples of OER programming that attend to care and student voice and offer related strategies for practitioners to consider.

Originality/value - Librarians at many post-secondary institutions provide critical advocacy and support the adoption, adaptation and creation of OER in higher education. Theories of care, values and ethics in the open education movement and librarianship provide a foundation for librarians to attend to care and elevate student voice as they undertake OER advocacy and initiatives.
\end{abstract}

Keywords Higher education, Academic librarians, Open education, Care, Student voice, Open educational resources (OER)

Paper type Case study

\section{Introduction}

At many post-secondary institutions, including the University of Colorado Boulder (CU Boulder), librarians actively advocate for increased awareness and adoption of open educational resources (OER). They undertake this work with intentions to reduce students'

(C) Merinda McLure and Caroline Sinkinson. Caring for Students in Postsecondary Open Educational Resource (OER) and Open Education Initiatives: Inviting Student Participation and Voice by Merinda McLure and Caroline Sinkinson is licensed under CC BY 4.0

The authors would like to acknowledge Lev Szentkirályi, $\mathrm{PhD}$, who welcomed the authors' work with WRTG 1150 and WRTG 3035 students; Melissa Cantrell, valued Libraries OER Co-Lead and Scholarly Communication Librarian in the CU Boulder Libraries; Leslie Reynolds, valued Open CU Boulder team member and Senior Associate Dean of Libraries at CU Boulder; and the students and colleagues who inspire and further the authors' work to advocate for OER and advance open education initiatives at the University of Colorado Boulder.

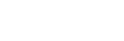


RSR

48,3

cost of attendance, improve their access to higher education and strengthen their learning experiences. The CU Boulder librarians leading these efforts have collaborated with campus entities such as the bookstore and registrar, advocated for the support of university administration, and engaged teaching faculty to promote OER adoption broadly across curricula. The authors and their library colleagues are well situated to engage in this work due to prior collaborations with a wide variety of campus colleagues, as well as position responsibilities that give them the privilege of working between and across disciplines. At CU Boulder and other post-secondary institutions, librarians' institutional positions enable libraries to be "hotbeds of collaboration and innovation" in advancing OER initiatives (Walz, 2017, p. 147). While librarians' relationships with educators, staff and administrators make it possible to carry out this work effectively, students and their learning are the inspiration motivating many librarians to engage in OER advocacy and initiatives.

In this article, the authors draw attention to theories of care to reframe practices that librarians may use to elevate student voice as they shape and implement OER initiatives. Accepting that "both education and openness, in their deepest and truest senses, seem to converge on relationships of generosity and care between human beings" (Wiley, 2015), the authors examine the guiding principles of open education and librarianship to identify complementary values of care. Next, the authors return attention to learners to answer the questions: What does it mean to care for students while advocating that educators adopt OER and explore open pedagogies? How can librarians support student agency as students learn about OER and develop their own opinions and perspectives? The authors identify approaches to open education that center care for student agency and voice, and consider how these models have influenced the authors' work at CU Boulder. They reflect on the development of their interest in attending to students and their hopes and intentions for their future OER advocacy and initiatives.

\section{Care in libraries}

Librarianship has a deep heritage of defending intellectual freedom and associated rights of access and education. The Library Bill of Rights states that libraries should strive to "cooperate with all persons and groups concerned with resisting abridgment of free expression and free access to ideas" (American Library Association, 2019). In the years since the original bill was authored in the 1930s, library practitioners have defined the protection of these rights and a commitment to intellectual freedom as a broad social responsibility of library professionals (Critical Librarianship, 2007). In the USA, the American Library Association has made visible in the Library Code of Ethics the principles that guide their work and affirmed a responsibility and commitment "to intellectual freedom and the freedom of access to information" (American Library Association, 2008). The right of individuals to seek and encounter information from diverse perspectives and points of view relies on access to education and learning and the principles of librarianship align directly with the United Nations Universal Declaration of Human Rights (American Library Association Council, 2019; United Nations General Assembly, 1948). The declaration affirms that "everyone has a right to education" that is essential for cultivating "respect for human rights and fundamental freedoms" and to strengthen broad understanding and tolerance across difference (United Nations General Assembly, 1948).

The degree to which an individual librarian identifies as a human rights advocate varies. However, many library-related campaigns and initiatives concerning issues such as banned books, censorship, the decriminalization of homelessness and privacy signal librarians' allegiance with ethics of caring for humanity and protecting individual freedoms. As the open education movement shares resonant values of social responsibility, intellectual 
freedom and access to education, it is unsurprising that librarians have gravitated toward this movement and have become critical advocates for OER and open education.

\section{Care in open education}

The open education movement emphasizes a commitment to humanity and the intention to repair systems that jeopardize equitable access to education. At the core of open education is a concern for human rights, articulated in the declarations and resolutions that guide the open education community. Since the coining of the term OERs in 2002 (United Nations Educational, Scientific and Cultural Organization, 2002), enthusiasm for OER has been tied to broader goals of democratizing education and supporting educational rights for all individuals (United Nations General Assembly, 1948). The United Nations Educational, Scientific and Cultural Organization (UNESCO) has fostered collaboration among educational organizations and governments to articulate and extend the potential of OER through declarations, action plans and most recently the 2019 Recommendations for OER (Miao et al., 2019; United Nations Educational, Scientific and Cultural Organization, 2002, 2012, 2017b, 2019). These documents work to set international standards and encourage policy development that supports the pursuit of OER adoption worldwide. Furthermore, these documents align with UNESCO's 2030 Agenda, specifically, the fourth sustainable development goal (SDG4), which aspires to "ensure inclusive and equitable quality education and promote lifelong learning opportunities" (United Nations Educational, Scientific and Cultural Organization, 2017a).

These documents have become guideposts for the open education community. They express a commitment to securing education for all by repairing barriers to access and encouraging educational opportunities that respect human dignity and cooperation. The authors of the Cape Town Open Education Declaration (2007) aspire toward pedagogies that cultivate relationships between learners and educators who "create, shape and evolve knowledge together, deepening their skills and understanding as they go." The signatories of the declaration commit to a rights-based approach to education that encompasses "the right of access to education," "the right to quality education," and "the right to respect within the learning environment" (UNICEF and UNESCO, 2007, p. 28). The declaration highlights "collaborative learning" and a "participatory culture of learning" where learners have "more control over learning" (Cape Town open education declaration: unlocking the promise of open educational resources, 2007). Here, learners' agency and the relational nature of learning are established as key components for realizing the goals of open education.

\section{Ethics of care}

Social responsibility and relationality are central convictions of both open education and librarianship. The trend in higher education, however, diverges away from relationality and care by emphasizing individuality (Lynch, 2010). According to Lynch, a scholar and pioneer of equity studies in education, this divergence can be traced back to the division of emotion and cognition in Cartesian influenced institutions of higher education. This trajectory means that infusing care into educational practices is not an activity that is typically normalized among educators (Motta and Bennett, 2018). Nonetheless, since the 1980s, researchers have built upon feminist frameworks introduced by Gilligan and Noddings, that position care as an ethical imperative and essential element in the relationship between teacher and learner (Owens and Ennis, 2005, p. 392). These frameworks describe reciprocal relationships between the caregiver and the one cared for to foster dialogue, listening and sharing in teaching and learning (Noddings, 2005). As theories of care have matured, theorists have distinguished between the traditional view of caring as an individualistic relationship 
RSR

48,3

between two parties, and an understanding of care as a collective approach to everyday social, political or educational life (Fisher and Tronto, 1990, p. 38).

Tronto, a leading scholar on the ethics of care and professor of political science, asserts that the need for care is a fundamental reality of humanity. Although individuals' care requirements may differ, all "humans have needs that others must help them meet" (Tronto, 1993, p. 110). This vision of care contrasts an image of a care relationship between a mother and child, or between the powerless and powerful, supporting arguments against notions of care as isolated to private and domestic spheres (Fisher and Tronto, 1990, p. 39). Tronto and Fisher define care as "everything that we do to maintain, continue and repair 'our world' so that we can live in it as well as possible" (1990, p. 40). They position care as a collective effort for social survival and democracy, and therefore education has a caring dimension (1990, p. 39). This resonates with the open education movement's commitment to repair access to education and to encourage relationships of sharing and cooperation.

Tronto, seeing a need to establish a more complex understanding of care, offers a framework for democratic, caring relationships that focuses on "needs, and on [the] balance between care-givers and care-receivers" (1993, p. 171). This theory of care seeks symmetry in caring relationships. In the context of open education initiatives, this requires that educators remain attentive to the particular needs and expressions of learners on whose behalf they are pursuing open, authentically asking who benefits from open education (Edwards, 2015, p. 254). The integrity of caring relationships depends on attentiveness, responsibility, competence, and responsiveness, and so caring must "start from the standpoint of the one needing care or attention" (Tronto, 1993, p. 19). This requires beginning with listening, inviting individuals to express their needs and positions, and determining actions based on the care-receiver's perspective and input (Tronto, 1993, p. 136).

\section{Care and open educational resources}

Increasingly, educators committed to open practices in education have expressed the need to consider critically the motivations powering open initiatives and to ensure prioritization of a "commitment to prevent harm" (Archer and Prinsloo, 2017, p. 281). This call requires that educators approach learners not as users of open resources but as whole human beings with vulnerabilities and needs (Archer and Prinsloo, 2017, p. 282). Care is complex and dynamic, requiring attentiveness and reflection from educators who wish to honor the whole student and to approach them with a strength-based (rather than deficit) perspective (Motta and Bennett, 2018, p. 640). Drawing from Nodding's distinction of relational care and virtuous care, Richard and Caines further caution against weaponizing care as a means to defend surveillance and tracking prevalent among many open and digital tools (Caines and Richard, 2020). Their warning offers a necessary reminder that open is not neutral and demands a critical approach that concentrates on care and repairing our worlds. Indeed, "care is a critical analytic lens" with which educators may confront the tensions inherent in opening education and protecting communities from unintended harm (Henry, 2019).

\section{Libraries and open educational resources}

Libraries' organizational structures, and librarians' skills and expertise support librarian engagement in implementing and sustaining OER initiatives. Green and Jhangiani (2019) observe that librarians are well-positioned by their consultative and collaborative roles in education and information services. Librarians possess skills related to discovery, archiving, copyright and licensing, and can contribute teaching and learning expertise. These skills are exceptionally valuable when facilitating education about and encouraging investment in open education (2019). 
Librarians have successfully leveraged their skills and expertise to provide faculty professional development concerning OER and open educational practices. They encourage educators to explore the financial threats and challenges students face, and how open licensing and open content can decrease students' costs, positively impact teaching, and improve learning experiences. Libraries have invested in programs to support faculty in creating and sharing OER and these frequently award faculty participation with stipends of $\$ 200$ to $\$ 6,000$ (Reed and Jahre, 2019). They have leveraged existing institutional repositories to host and disseminate open textbooks and other OER resulting from library publishing programs. Throughout this work, librarians share their open licensing expertise with faculty creators of OER (Batchelor, 2019; Kleymeer et al., 2010). Furthermore, librarians' broad academic connections position them to advocate for consortial partnerships, statewide initiatives, dedicated personnel and other collaborations and investments to advance OER uptake in higher education (Bell and Salem, 2017; Waller et al., 2019; Walz, 2017).

Although librarians have demonstrated how to ameliorate the high cost of course materials by advancing the proliferation of OER, they have done so in large part by engaging faculty and administrators, rather than students. The open education community calls upon educators and librarians to "commit to actively bring students and early career educators into the movement as users, advocates, and creators of OER" Cape Town Open Education Declaration (2017, p. 6). This charge echoes the emphasis on listening to carereceivers that is found in care ethics.

\section{Libraries and learners}

Learners and student advocates have long been part of the open education movement and continue to contribute to its progress (Reed and Jahre, 2019, p. 5). Student Public Interest Research Groups (PIRGs), for example, have organized students, staff and faculty to advocate for OER adoption. These groups have gathered more than 3,000 faculty signatures in support of open textbooks, authored student advocacy toolkits, exposed predatory publishing practices, published OER research reports and pursued other impactful activities (Student PIRGs, 2020). More than seven million students in North America participate in activism for open access research through the Right to Research Coalition (Right to Research Coalition, 2010). On individual campuses across the continent, students have led high-profile campaigns such as \#TextbookBroke that increased awareness of course material costs and encouraged students to contact campus and government policymakers (Student Government Resource Center, 2014). These activities provide evidence of a desire among learners to be heard and to participate in the OER initiatives of faculty, librarians and administrators.

Baker and Ippoliti (2018) found a lack of formal publications about including student voices in campus OER initiatives. Blog posts and local news postings, however, reveal accounts of librarians who have partnered with student government to host student panels, have engaged in open pedagogy and have undertaken concerted efforts to amplify student voices in open education and OER programming. Librarian partnerships with student government associations (SGA) leverage the advocacy, leadership and legislative roles that student government members hold on behalf of the student body. SGAs have preestablished communication mechanisms, dedicated budgets and influence at state and campus levels that may boost awareness of the burden of course material costs. National student government organizations such as the Open Textbook Alliance have demonstrated a commitment to OER. They have established fertile ground for collaboration by releasing 
RSR

48,3

student government toolkits for making textbooks affordable (Open Textbook Alliance, 2020).

Caldwell et al. (2018) suggest beginning SGA collaborations through targeted outreach that includes education about the burden of course material costs, successful and pending legislation addressing these costs, and funding opportunities for campus initiatives. By equipping SGA representatives with information and resources, such as the Open Oregon Manifesto for OER (Open Oregon, 2018), students are poised to become spokespersons for OER. At the University of Florida, librarians presented and arranged workshops at regional and local SGA gatherings, meeting SGA representatives in pre-established training sessions (Caldwell et al., 2018). Texas A\&M librarians took another approach, participating in outreach efforts as part of a Southeastern Conference workshop convening learners and faculty from 13 institutions to consider open education and open access (Herbert, 2016). These efforts ultimately led to the establishment of OER Teaching Awards jointly coordinated by the libraries and the SGA (Caldwell et al., 2018; Herbert, 2016). Similar award models (Hendricks, 2017; University of Hawai'i, 2019) present the opportunity to celebrate open educators while increasing visibility of OER initiatives to a broad audience. Students have the opportunity to feel a sense of ownership through their nomination and selection of award recipients and may gain awareness of faculty decision-making in selecting course content (Caldwell et al., 2018). In addition to partnering with librarians to offer awards, several student governments have successfully drafted and passed campus legislation and policies for campus-wide OER commitments (Dupuis, 2017; Grguras et al., 2018; Herbert, 2016; University of Edinburgh, 2016).

Among the most compelling examples of inviting student participation in OER efforts are those that capture authentic student narratives confronting the costs of higher education. Lumen Learning hosts a guide that recommends steps and strategies for arranging student panels and discussions, provides a series of possible questions, includes tips for selecting a spokesperson and suggests methods for sharing final productions of the panels (Lumen Learning, 2017). Examples of student panels include "Why OER <www. youtube.com/watch?v=-EEGTfjS3Ak\&feature=youtu.be >” from Mount Holyoke College, an OpenEd 2017 conference panel of Santa Ana College <www.youtube.com/watch?v= $\mathrm{vtPm} 3 z \mathrm{zSfW}$ o\&feature=youtu.be $>$ students, as well as students' opinions of zero textbook cost courses from Kingsborough College $<$ www.youtube.com/watch?v=YpLTfr9T2Z0\& feature=youtu.be $>$ (Lumen Learning, 2017).

Campaigns such as these invite students to share perspectives with a broad audience, thereby contributing to awareness of OER programs. Approaching the inclusion of student voice from a more formal and long-term perspective, the University of Edinburgh established a student internship program. These Open Content Curator Interns work with professional staff to shape and extend the OER program through compilation and review of OER (Farley, 2016; Ferguson, 2019). Similarly, the University of Calgary employed undergraduates to conduct reviews of OER and to match those to existing campus curricula (Adams, 2017). These initiatives invite students to participate in shaping the trajectories of OER programming.

Student voice is also prominent in examples of open pedagogy such as co-authoring textbooks (DeRosa, 2016), co-writing syllabi or assignments (Nelson, 2019) or collaborative writing for Wikipedia (Villenueve, 2018). Champions of open pedagogy Robin DeRosa and Rajiv Jhangiani founded the Open Pedagogy Notebook which collects and compiles examples of these practices and includes contributions from librarians. DeRosa and Jhangiani define open pedagogy as "a site of praxis, a place where theories about learning, teaching, technology, and social justice enter into a conversation with each other and inform 
the development of educational practices and structures" (DeRosa and Jhangiani, 2018). They encourage faculty to "build OERs with your students," advocating that "asking students to help reframe and re-present content in new and inventive ways can add value to the commons" (DeRosa and Jhangiani, 2018). Among the strategies and examples they share are student-teacher partnerships in authoring and curating knowledge hubs such as Wikipedia, to enhance digital literacies and enrich the knowledge commons (Salvaggio, 2016). They also include recommendations for inviting learners to undertake research assignments with authentic community partners (Rosenthal, 2006). In all of these examples, the primary impetus is to invite learners into the creation of their learning experiences.

\section{Engaging University of Colorado Boulder students in learning about and advocating for open educational resources}

The authors at the University of Colorado Boulder have supported student OER advocacy through collaboration with a writing instructor on service-learning assignments. They designed the assignments to facilitate students' learning about OER. The authors have also engaged student government and student learners in celebrating educators with a campus Open Educator Award.

\section{Open educational resources momentum in Colorado and on campus}

OER garnered new attention at CU Boulder in 2017 when the student government's president of internal affairs became a passionate advocate for increasing OER awareness and adoption, concurrent with the passage of new state legislative support for OER and a significant CU Boulder commitment to reduce students' cost of attendance. Colorado Senate Bill 17-258 Using Open Educational Resources In Higher Education (Lundberg and Rankin, 2017) created a state OER Council in the Colorado Department of Higher Education, charged with investigating and reporting by November 2017 the status of OER awareness and adoption at post-secondary institutions across the state. The Council's recommendations (Colorado Open Educational Resources Council, 2017) contributed to the subsequent passage of House Bill 18-1331 Higher Education Open Educational Resources (Young et al., 2018a) that created a renewed Colorado OER Council and state OER grant program, both term-limited through November 2021. The Council was charged with executing educational initiatives and disbursement of up to $\$ 500,000$ in OER grants in the state fiscal year 20182019 and up to \$1m in 2019-2020 (Young et al., 2018b). At CU Boulder in fall 2017, the chancellor committed $\$ 1 \mathrm{~m}$ to support a transition to OER and affordable course materials. This commitment was part of the broader BeBoulder Pact to reduce students' cost of attendance and eliminate $\$ 8.4 \mathrm{~m}$ annually in course-related fees paid by students (Strategic Relations, 2017), and the student government's president of internal affairs was instrumental in advocating for this commitment. In spring 2018, the CU Boulder provost charged a new campus OER Advisory committee (Strategic Relations, 2018) with investigating OER trends (nationally and at CU Boulder) and recommending how the chancellor's $\$ 1 \mathrm{~m}$ should be invested to lower the cost of materials and supplies for CU Boulder students. The committee, co-chaired by the Libraries' senior associate dean and the student government president of internal affairs, submitted its recommendations in November 2019.

Robust campus and state momentum around OER continue today. CU Boulder and other Colorado post-secondary institutions are preparing to denote in course catalogs and registration systems courses that use OER or have low course-materials costs. This work will need to be completed in time for the Fall 2021 semester in compliance with the requirement of House Bill 18-1331. These course markings have the potential to increase 
RSR

48,3

students' awareness of and curiosity about OER, as well as student agency in selecting courses and committing to the associated course-materials costs. The authors, with Libraries and CU System colleagues, received grant funding from the Colorado Department of Higher Education to support OER programming in 2019-2020 and 2020-2021. In 2019, the team executed educational workshops about OER, engaged participating educators in the review and evaluation of open textbooks, and supported nine educators in integrating OER into Spring 2020 courses. The team will refine and extend these initiatives in 2020 2021.

\section{Engaging students in course-based exploration of open educational resources}

In the Spring 2018 and Spring 2019 semesters, the authors collaborated with an instructor to co-design and support course assignments to engage students in exploring OER. The authors' support of students in these course learning experiences significantly inspired and developed the authors' consideration of care and student voice in OER advocacy.

Writing 3035: supporting students in learning about open educational resources and peer perspectives. In the Spring 2018 semester, the authors collaborated with an instructor on the design of assignments for this course. The instructor structured the primary assignment as a small-group service-learning project and invited the authors to be a campus client for several groups. The authors hoped to learn more about CU Boulder student perspectives concerning OER and wanted to better integrate student voices into OER work on campus. The authors also aimed to support these students in learning about OER in relation to the students' experiences as participants in higher education. They hoped to facilitate student agency in developing independent perspectives on OER and related issues such as course materials costs. Seven students, working in two separate groups, set out to learn about OER and to design and execute brief interviews to collect the perspectives of campus peers.

The authors supported student learning by providing an in-class introduction to OER, a collection of resources about OER and interview best practices. Over the course of the semester, the authors offered support through email correspondence and multiple consultations with each student group. The course instructor provided the assignment framework and additional support, helping students finalize interview questions and execute best practices in their interviews, assisting when interviewee recruitment proved challenging and providing instruction in interview transcription.

The authors found their work with these students - juniors and seniors from fields including media design, engineering, communications and computer science - to be inspiring and educational. The authors foregrounded student reflection in their consultations with students and in their recommendations for the students' final reports. The perspectives and opinions the students shared themselves, and on behalf of the peers they interviewed, communicated students' desire for voice and agency in their educational experiences. These final reports included comments such as:

[...] allowing the students to take charge and use their voices to shape OER will ensure; that it [OER] is actually meeting their needs and not falling short of student expectations; we also suggest empowering students to share the story and vision of OER through; articles and media on campus to grow the conversation and awareness of existing; and developing OER at CU.

This work with students allowed the authors to experience and reflect upon the relational nature of learning. In sharing expertise and curating a collection of resources to support and pragmatically scope students' investigation of OER, the authors were also conscious of interrupting students' developing understanding of OER with the authors' biases. The 
authors gained an increased awareness of the importance of explicitly distinguishing and claiming their perspectives and opinions concerning OER as personal and selective. They were gratified that students went beyond the curated collection of resources in their research into OER.

Writing 1150: engaging students in listening to advocates and adopters. In the Spring 2019 semester, the authors worked with the same instructor, and 18 students enrolled in a first-year writing class. The students were divided into three groups for their work on the course service-learning assignment. The authors guided the students as they explored OER and facilitated a more in-depth investigation through interviews with campus OER adopters and advocates, including librarians, administrators, educators and instructional design and online learning experts. The authors provided additional support through consultations, curated resources and individual coaching, while the instructor provided assignment scaffolding and guidance.

The students designed prototypes for postcards, brochures and webpage templates that showcase profiles of campus advocates alongside information about OER, which the authors found inspiring and informative. Students were impressed that advocates and adopters expressed care for students in their interviews, and students saw these stories as holding the untapped potential to encourage new participation in the growing campus OER community. The students captured many recommendations in their final reports, such as:

We think it is entirely possible to start a mini-revolution on CU's campus with the faculty who already support OER, with these key staff that can push to make textbooks more affordable and push for other staff to check out the resources already available to them and even that they can produce their own material. We believe a huge part of the push from the OER comes from the faculty talking to their fellow peers and trying to show them the positives of OER and what they can benefit from OER as well as what their students can benefit. Staff members need to start pushing and breaking the silence when talking to their colleagues about OER.

Through these experiences working with writing students, the authors gained a heightened appreciation for encouraging student agency in learning about and developing opinions and perspectives on OER from students' unique vantage point as participants in higher education. The authors learned from listening to students, participating in their learning process and reflecting on the importance of grounding OER advocacy in the expressed interests and needs of students, on whose behalf the authors undertake this work.

\section{Partnering with student government to celebrate open educators}

In 2018, the Libraries' team of OER librarians, known as the OER Leads, initiated an annual CU Boulder Open Educator Award (University Libraries, 2020a) co-sponsored by the CU Boulder Student Government (CUSG) (CU Boulder Student Government (CUSG), 2020) and the University Libraries.

The award elevates campus awareness of and conversation about OER and honors campus educators who contribute to the open movement. It recognizes up to three CU Boulder educators each year who have implemented, adapted or authored high-quality OER. Awardees are selected based on their educational impact and innovative contributions to a culture of open knowledge sharing and access. The recipients are honored with a small gift and an article that profiles the educator's motivations, aspirations and accomplishments in advancing the use of OER in teaching.

The Texas A\&M Student Government Association (SGA) Open Educator Award (Texas A\&M University Libraries, 2019) and the University of Tennessee Knoxville Student Government Association (SGA) Open Education Award (University Libraries, 2020b) 
RSR

48,3

482

inspired CU Boulder librarians to invite the CUSG in co-sponsoring the Open Educator Award with the Libraries. The OER Leads engage the CUSG in publicizing the award, encouraging nominations by CU Boulder's student community and affirming the recipient(s). Diverse members of the campus community, including students, have nominated educators each year, and recipients have expressed feeling deeply honored to receive the award. Especially noteworthy are nominations by students who express appreciation for no or low course-materials costs, compliment educators' exemplary integration of learning resources and applaud educators' unique pedagogical practices. That educators are deeply appreciative to receive an honorary award recognizing their attention to both student course-materials costs, and the many affordances of OER seem in step with the call for a persistent practice of care that is integral to the open education movement.

\section{Supporting educators engaging students in open education}

In 2019 and the Spring 2020 semester, the OER Leads, and the Libraries' senior associate dean have as an "Open CU Boulder" team facilitated significant professional development for CU Boulder faculty, instructors and graduate part-time instructors. Throughout this work, the authors have noted opportunities to support educators who may engage students in learning about and adapting or creating OER.

This work is part of "Open CU: Building a Sustainable OER Initiative Across the University of Colorado," a collaboration with CU System colleagues that is funded by a grant from the Colorado Department of Higher Education (CDHE) OER grant program (Colorado Department of Higher Education, 2019). The CU Boulder team has provided 52 educators with an educational workshop about OER and open licensing, and engaged them in authoring reviews of existing open textbooks (adapting a model created by the Open Education Network). The team has also supported nine educators in incorporating OER into Spring 2020 courses, initiating their work with a more comprehensive, day-long workshop about OER, open licensing and open pedagogy. All participating educators receive stipends funded by the grant. The CU Boulder team will expand and continue this work through 2021 as "Open CU: Expanding a Successful OER Initiative" (Colorado Department of Higher Education, 2020), also undertaken with CU System colleagues and funded by a second CDHE OER grant.

In the course of this work in 2019, the OER Leads were inspired to work with the CU Boulder Office of the University Counsel to create a "Student Agreement to Publish Course Work under a Creative Commons License: University of Colorado Boulder Libraries (2019), (University of Colorado Boulder Libraries, 2019) adapted from the agreement authored by the Kwantlen Polytechnic University Office of Open Education (Kwantlen Polytechnic University Office of Open Education, 2020). This agreement clarifies several issues pertinent to educators who may involve students in open licensing, including CU Boulder's "Intellectual Property That is Educational Materials" policy (University of Colorado, 2013). It provides educators with a tool for educating their students about open licensing and dovetails with complimentary efforts for open pedagogy currently underway (Sinkinson and McAndrew, 2020). The authors thus view this agreement as another small effort to intentionally weave into their OER advocacy attention to student agency and voice and care for students but also educators.

\section{Conclusion and future directions}

The authors see many opportunities to center student participation and student voice in future work by building upon these experiences and continuing to draw on models provided by other librarians and educators. 
Inviting student presenters and panelists into CU Boulder OER workshops for educators, and asking educators and administrators to listen attentively to these students will be an important next effort. Creating space to allow students to actively influence OER programming and initiatives is a significant goal that will require the authors to consider new logistics, such as allowing for students' busy and different schedules and integrating additional communications and meeting time into the authors' OER work. As the authors seek to turn new attention to supporting student OER advocacy, invested and careful concern with both student agency and student vulnerability will be paramount. New possibilities, such as the Libraries' support of student interns focused on OER, will engage the authors in carefully designing student learning experiences that foremost benefit these students and only secondarily support the authors' and Libraries' interests in advancing OER awareness and adoption at CU Boulder.

To guide these future efforts, the authors are designing a values framework that explicitly communicates their commitment to care ethics in their open education work. The authors will seek feedback from students, colleagues, administrators and partners within and beyond CU Boulder to strengthen and develop the framework over time. The authors anticipate that the framework will help them negotiate commonly-encountered tensions in open education work, including institutional and funder preference for quantifiable and timely outcomes such as student savings, and advocating for evaluating the more nuanced outcomes of student engagement and students' development of knowledge and agency as participants in open education.

In this article, the authors have identified motivations to mend and repair educational systems shared by librarianship and the open education movement and have explored concepts of care that might direct and focus existing and future programming. Ethics of care encourage librarians to pursue careful connections with learners that build meaningful and symmetrical relationships intent on supporting the rights of education. Investigating caring concepts, the authors have offered a method for framing open education that centers attention on relationships with students. Encouraged by these initial investigations, the authors are inspired to continue exploring theories and conceptions of care. They look forward to opportunities within the profession to collectively progress practices librarians may use to elevate student agency and voice in open education.

\section{References}

Adams, C. (2017), "Stars align for OER expansion at University of Calgary, SPARC", available at: https://sparcopen.org/news/2017/stars-align-oer-expansion-university-calgary/ (accessed 20 January 2020).

American Library Association (2008), "Code of ethics”, available at: www.ala.org/tools/ethics (accessed 26 February 2020).

American Library Association (2019), "Library bill of rights", available at: www.ala.org/advocacy/ intfreedom/librarybill (accessed 27 February 2020).

American Library Association Council (2019), "Education and information literacy: an interpretation of the library bill of rights", available at: www.ala.org/advocacy/intfreedom/librarybill/ interpretations/education (accessed 26 February 2020).

Archer, E. and Prinsloo, P. (2017), "Some exploratory thoughts on openness and an ethics of care", in Singh, D. and Stuckelberger, C. (Eds), Ethics in Education: Value-Driven Leaders for the Future, Globethics.net, Geneva, pp. 273-286, available at: www.globethics.net/documents/4289936/ 20368389/GE_Education_Ethics_1_isbn9782889311644.pdf (accessed 18 May 2020). 
RSR

48,3

Baker, A. and Ippoliti, C. (2018), "Student-driven OER: championing the student voice in campus-wide efforts", in Wesolek, A., Lashley, J. and Langley, A. (Eds), OER: A Field Guide for Academic Librarians, Pacific University Press, available at: https://boisestate.pressbooks.pub/oer-field-guide/ chapter/student-driven-oer-championing-the-student-voice-in-campus-wide-efforts/ (accessed 24 January 2020).

Batchelor, C. (2019), "Transforming publishing with a little help from our friends: supporting an open textbook pilot with friends of the libraries grant funding”, in Wesolek, A., Lashley, J. and Langley, A. (Eds), OER: A Field Guide for Academic Librarians, Pacific University Press, available at: https://boisestate.pressbooks.pub/oer-field-guide/chapter/an-open-athenaeumcreating-an-institutional-home-for-open-pedagogy/(accessed 1 May 2019).

Bell, S.J. and Salem, J.A. (2017), "It's up to the librarians: establishing a statewide OER initiative", Pennsylvania Libraries: Research and Practice, Vol. 5 No. 2, pp. 77-82.

Caines, A. and Richard, S. (2020), "DigCiz weaponization of care", Presented at OER20, available at: https://oer20.oerconf.org/news/2020/02/digciz-weaponization-of-care-by-autumm-caines-andsundi-richard/ (accessed 18 May 2020).

Caldwell, R., Sandelli, A. and Doncaster, H. (2018), "How to establish an SGA open education award on your campus", Presented at the 15th Annual Open Education Conference, 10-12 October, Niagara Falls, New York, NY.

Cape Town open education declaration: unlocking the promise of open educational resources (2007), Cape Town, South Africa, available at: www.capetowndeclaration.org/ (accessed 30 October 2017).

Cape Town Open Education Declaration (2017), available at: www.capetowndeclaration.org/cpt10/ (accessed 27 February 2020).

Colorado Department of Higher Education (2019), "Colorado OER council, Colorado rises", available at: http://masterplan.highered.colorado.gov/oer-in-colorado/ (accessed 1 March 2020).

Colorado Department of Higher Education (2020), "Recommended award recipients for OER grant program year two", available at: http://masterplan.highered.colorado.gov/wp-content/ uploads/2020/02/Agenda-Item-II-A-Attachment-A-OER-Grantee-Award-List.pdf (accessed 1 March 2020).

Colorado Open Educational Resources Council (2017), "Report to the joint budget committee and the education committees of the general assembly: open educational resources in Colorado", Colorado Department of Higher Education, Denver, CO, p. 83, available at: https://highered. colorado.gov/Publications/Reports/legislative/OER/OER_Nov2017.pdf (accessed 1 March 2020).

Critical librarianship (2007), "Critical librarianship: an interview with Toni Samek", Intellectual freedom Committee - BCLA, available at: https://bclaifc.wordpress.com/2007/11/13/criticallibrarianship-an-interview-with-toni-samek/ (accessed 3 April 2019).

CU Boulder student government (CUSG) (2020), available at: https://custudentgov.org (accessed 1 March 2020).

DeRosa, R. (2016), "My open textbook: pedagogy and practice", actualham, available at: https:// robinderosa.net/uncategorized/my-open-textbook-pedagogy-and-practice/ (accessed 2 May 2019).

DeRosa, R. and Jhangiani, R. (2018), "Open pedagogy, open pedagogy notebook”, available at: http:// openpedagogy.org/open-pedagogy/ (accessed 22 February 2020).

Dupuis, D. (2017), "Viewpoint: student leaders unite around top priorities", available at: www.mass. edu/about/whatsnew_201801sac-ddupuis.asp (accessed 24 January 2020).

Edwards, R. (2015), "Knowledge infrastructures and the inscrutability of openness in education", Learning, Media and Technology, Vol. 40 No. 3, pp. 251-264, doi: 10.1080/17439884.2015.1006131.

Farley, C. (2016), “A student's perspective on open education”, available at: https://open.ed.ac.uk/astudents-perspective-on-open-education/ (accessed 27 February 2020). 
Ferguson, A. (2019), "From open source to open education", available at: https://open.ed.ac.uk/fromopen-source-to-open-education/ (accessed 7 February 2020).

Fisher, B. and Tronto, J. (1990), "Toward a feminist theory of caring”, in Abel, E. and Nelson, M. (Eds), Circles of Care: Work and Identity in Women's Lives, State University of New York, NY Press, Albany, New York, NY, pp. 35-62.

Green, A.G. and Jhangiani, R.S. (2019), "An open athenaeum: creating an institutional home for open pedagogy", in Wesolek, A., Lashley, J. and Langley, A. (Eds), OER: A Field Guide for Academic Librarians, Pacific University Press, available at: https://boisestate.pressbooks.pub/oer-field-guide/ chapter/an-open-athenaeum-creating-an-institutional-home-for-open-pedagogy/(accessed 1 May 2019).

Grguras, S. et al. (2018), "Calling upon the University of Pittsburgh to adopt open educational resources", University of Pittsburgh, available at: https://sgb.pitt.edu/government/governingdocuments-2/ (accessed 27 February 2020).

Hendricks, C. (2017), "Students have vital role in creating and spreading OER", Inside Higher Education, available at: www.insidehighered.com/digital-learning/views/2017/12/13/studentshave-vital-role-creating-and-spreading-oer (accessed 24 January 2020).

Henry, J.V. (2019), "Opening up the trouble with care", presented at OER20, available at: https://oer20.oerconf. org/news/2019/12/opening-up-the-trouble-with-care-by-jade-vu-henry/ (accessed 18 January 2020).

Herbert, B.E. (2016), “Texas A\&M student government OER teaching awards”, available at: https:// oaktrust.library.tamu.edu/handle/1969.1/156092 (accessed 24 January 2020).

Kleymeer, P., Kleinman, M. and Hanss, T. (2010), "Reaching the heart of the university: libraries and the future of OER", Presented at the 7th Annual Open Education Conference, Barcelona, Spain.

Kwantlen Polytechnic University Office of Open Education (2020), "Student agreement to publish course work under a creative commons license", available at: https:/t.co/02vDd65BZP (accessed 1 March 2020).

Lumen Learning (2017), "Student panel", available at: https://lumenlearning.com/student-panel/ (accessed 7 February 2020).

Lundberg, K. and Rankin, B. (2017), "Using open educational resources in higher education”, available at: https://leg.colorado.gov/bills/sb17-258 (accessed 1 March 2020).

Lynch, K. (2010), "Carelessness: a hidden doxa of higher education", Arts and Humanities in Higher Education, Vol. 9 No. 1, pp. 54-67, doi: 10.1177/1474022209350104.

Miao, F. Mishra, S. Orr, D. and Janssen, B. (2019), "Guidelines on the development of open educational resources policies", UNESCO; commonwealth of learning (COL)", available at: http://oasis.col. org/handle/11599/3455 (accessed 22 February 2020).

Motta, S.C. and Bennett, A. (2018), "Pedagogies of care, care-full epistemological practice and 'other' caring subjectivities in enabling education", Teaching in Higher Education, Vol. 23 No. 5, pp. 631-646, doi: 10.1080/13562517.2018.1465911.

Nelson, A. (2019), "Collaborative syllabus design: students at the center", Open Pedagogy Notebook, 19 March, available at: http://openpedagogy.org/course-level/collaborative-syllabus-designstudents-at-the-center/ (accessed 21 May 2019).

Noddings, N. (2005), "Caring in education', the encyclopedia of pedagogy and informal education", available at: http://infed.org/mobi/caring-in-education/ (accessed 30 November 2019).

Open Oregon (2018), "Manifesto for OER: textbook affordability student toolkit", Google Docs, available at: https://drive.google.com/file/d/1KW2OakEQVSGJdYL_CBPSorvohHHOaUEC/ view?usp=embed_facebook (accessed 23 February 2020).

Open Textbook Alliance (2020), "Making textbooks affordable", available at: https://studentgovresources. org/wp-content/uploads/2016/09/Open_Textbook_Alliance_Toolkit.pdf (accessed 7 February 2020).

Owens, L.M. and Ennis, C.D. (2005), "The ethic of care in teaching: an overview of supportive literature", Quest, Vol. 57 No. 4, pp. 392-425, doi: 10.1080/00336297.2005.10491864. 
RSR

48,3

Reed, J.B. and Jahre, B. (2019), "Reviewing the current state of library support for open educational resources", Collection Management, Vol. 44 Nos 2/4, pp. 232-243, doi: 10.1080/ 01462679.2019.1588181.

Right to Research Coalition (2010), "About our coalition”, available at: www.righttoresearch.org/about/ index.shtml (accessed 27 February 2020).

Rosenthal, L. (2006), "Mastering research methods with community projects", Action Teaching, available at: www.actionteaching.org/award/community-action (accessed 22 February 2020).

Salvaggio, E. (2016), "For Wikipedia, the doctor is in . . class", Wiki Education, available at: https:// wikiedu.org/blog/2016/04/05/medical-students-wikipedia/ (accessed 22 February 2020).

Sinkinson, C. and McAndrew, A. (2020), "Approaching open pedagogy in community and collaboration", in Davies, K. and Clifton, A. (Eds), Open Pedagogy: Varied Definitions, Multiple Approaches, Rebus.

Strategic Relations (2017), "BeBoulder pact to save student body $\$ 8.4$ million annually", CU Boulder Today, available at: www.colorado.edu/today/2017/10/17/be-boulder-pact-save-student-body-84million-annually (accessed 2 March 2020).

Strategic Relations (2018), "Open educational resources advisory committee, university of Colorado boulder", available at: www.colorado.edu/about/strategic-initiatives/campus-committees/openeducational-resources-advisory-committee (accessed 2 March 2020).

Student Government Resource Center (2014), “\#textbookbroke: campaign for affordable textbooks”, Student Government Resource Center, available at: https://studentgovresources.org/ textbookbroke-campaign-for-affordable-textbooks/ (accessed 27 February 2020).

Student PIRGs (2020), "Make textbooks affordable", Student PIRGs, available at: https:/studentpirgs. org/campaigns/make-textbooks-affordable/ (accessed 27 February 2020).

Texas A\&M University Libraries (2019), "Open educational materials awards”, Texas A\&M University Libraries, available at: https:/library.tamu.edu/services/scholarly_communication/ open_ed_awards.html (accessed 1 March 2020).

Tronto, J.C. (1993), Moral Boundaries: A Political Argument for an Ethic of Care, Routledge, New York, NY.

UNICEF and UNESCO (2007), "A human rights-based approach to education for all", UNICEF, New York, NY, available at: www.unicef.org/publications/files/A_Human_Rights_Based_Approach_ to_Education_for_All.pdf (accessed 1 March 2020).

United Nations Educational, Scientific and Cultural Organization (2002), "Forum on the impact of open courseware for higher education in developing countries", Paris, France, available at: https://webarchive.unesco.org/20151106014940/http://unesdoc.unesco.org/images/ 0012/001285/128515e.pdf (accessed 6 June 2019).

United Nations Educational, Scientific and Cultural Organization (2012), “2012 Paris OER declaration”, 2012 World Open Educational Resources (OER) Congress, available at: https:/en.unesco.org/ oer/paris-declaration (accessed 1 October 2012).

United Nations Educational, Scientific and Cultural Organization (2017a), "Sustainable development goal four", available at https://sustainabledevelopment.un.org/sdg4 (accessed 27 February 2020).

United Nations Educational, Scientific and Cultural Organization (2017b), "Second world OER congress Ljubljana OER action plan 2017", Ljubljana, Slovenia: 2nd World OER Congress, available at: https://en.unesco.org/sites/default/files/ljubljana_oer_action_plan_2017.pdf (accessed 18 November 2018).

United Nations Educational, Scientific and Cultural Organization (2019), "UNESCO recommendations on open education resources", Paris, France, available at: https:/drive.google.com/file/d/ 1N54rMUsvVO-9f1K-LN-pmkBQSto2wLRu/view?usp=embed_facebook (accessed 6 June 2019).

United Nations General Assembly (1948), "Universal declaration of human rights", available at: www. un.org/en/universal-declaration-human-rights/index.html (accessed 22 February 2020). 
University Libraries (2020a), “CU open educators”, available at: https://libguides.colorado.edu/c.php? $\mathrm{g}=907029 \& \mathrm{p}=6531003($ accessed 1 March 2020$)$.

University Libraries (2020b), "Student government association (SGA) open education award", University Libraries, The University of Tennessee Knoxville, available at: www.lib.utk.edu/ scholar/services/scholarlycomm/sga-open-educator-award/ (accessed 1 March 2020).

University of Colorado (2013), "Intellectual property that is educational materials", available at: www. cu.edu/ope/aps/1014 (accessed 1 March 2020).

University of Colorado Boulder Libraries (2019), "Student agreement to publish course work under a creative commons license", available at: https://libguides.colorado.edu/ld.php?content_id= 52732099 (accessed 1 March 2020).

University of Edinburgh (2016), "Open educational resource policy”, available at: www.ed.ac.uk/files/ atoms/files/openeducationalresourcespolicy.pdf (accessed 7 February 2020).

University of Hawai'i (2019), "Leeward CC open educational resources award winners 2019", University of Hawai'i OER, available at: https://oer.hawaii.edu/leeward-cc-open-educational-resourcesaward-winners-2019/ (accessed 23 February 2020).

Villenueve, C. (2018), "Editing Wikipedia in the classroom: individualized open pedagogy at scale", Open Pedagogy Notebook, available at: http://openpedagogy.org/course-level/editing-wikipediain-the-classroom-individualized-open-pedagogy-at-scale/ (accessed 2 July 2019).

Waller, J., Taylor, C. and Zemke, S. (2019), "From start-up to adolescence: University of Oklahoma's OER efforts", in Wesolek, A., Lashley, J. and Langley, A. (Eds), OER: A Field Guide for Academic Librarians, Pacific University Press, available at: https://boisestate.pressbooks.pub/oer-field-guide/ chapter/an-open-athenaeum-creating-an-institutional-home-for-open-pedagogy/ (accessed 1 May 2019).

Walz, A. (2017), “A library viewpoint: exploring open educational practices”, in Jhangiani, R.S. and Biswas-Diener, R. (Eds), Open: The Philosophy and Practices That Are Revolutionizing Education and Science, Ubiquity Press, London, pp. 147-162, available at: https://doi.org/10.5334/bbc.l

Wiley, D. (2015), "The deeper ethics of education and open: generosity, care, and relationships", Iterating Toward Openness, 15 January, available at: https://opencontent.org/blog/archives/3732 (accessed 20 February 2020).

Young, D. Rankin, B. and Lundberg, K. (2018a), "Higher education open educational resources", available at: https://leg.colorado.gov/bills/hb18-1331 (accessed 1 March 2020).

Young, D. Rankin, B. and Lundberg, K. (2018b), "Higher education open educational resources, fiscal note", available at: https:/leg.colorado.gov/sites/default/files/documents/2018A/bills/fn/ 2018a_hb1331_f1.pdf (accessed 2 March 2020).

\section{Corresponding author}

Caroline Sinkinson can be contacted at: Caroline.Sinkinson@Colorado.EDU

For instructions on how to order reprints of this article, please visit our website:

www.emeraldgrouppublishing.com/licensing/reprints.htm

Or contact us for further details: permissions@emeraldinsight.com 